\title{
The Level of Clinical Improvement in Sexually Abused Children Admitted to an Inpatient Child and Adolescent Mental Health Unit
}

Burcu Serim Demirgoren $\odot$
Taner Guvenir $\odot$
Oguzhan Simsek $\odot$
Bahar Sen $\odot$

\author{
Cinsel Istismar Nedeniyle Bir Çocuk ve Ergen \\ Psikiyatrisi Yataklı Servisinde Tedavi Gören \\ Olgularda Klinik iyileşme Düzeyi
}

\begin{abstract}
Objective: Child sexual abuse is a major psychosocial problem, often leading to lifelong adverse consequences and impairments for the victims. The association between child abuse and psychiatric diagnosis has been shown via cross-sectional and longitudinal studies. The aim of this study was to measure, and determine the clinical improvement in patients who had been diagnosed with child sexual abuse and received inpatient treatment in a child and adolescent mental health unit.

Method: The study sample included all of the 43 children and adolescents, aged 8-18 years, who were treated in the inpatient unit from 2005-2018 for exposure to sexual abuse. Data, including sociodemographic features, individual and familial risks, Children's Global Assessment Scale scores, and the Turkish version of Health of the Nation Outcome Scales-Children and Adolescents scores (HoNOSCA-TR), all of which were routinely calculated at admission and discharge, were collected retrospectively from the hospital's records.

Results: Results demonstrated that the average duration of stay at the unit was $85.74 \pm 30.54$ days. General functionality measured by the Children's Global Assessment Scale significantly increased from admission to discharge following psychiatric inpatient treatment $(p<0.05)$. Moreover, there was also significant improvement in sexually abused children and adolescents as indicated with all of the HONOSCA-TR subscales $(p<0.05)$.

Conclusion: Our study demonstrates that sexually abused young people benefit from inpatient treatment and that milieu therapy, which facilitates positive and reparative social interactions with peers and members of the therapeutic team during daily activities and therapeutic interventions, is a primary contributor to sexually abused young patients successfully managing to improve their functioning.
\end{abstract}

Keywords: Child sexual abuse, inpatient treatment, milieu therapy, improvement

Öz

Amaç: Çocuğun cinsel istismarı, mağdurlar üzerinde yaşam boyu süren olumsuz sonuçlara ya da bozukluklara neden olabilmesi nedeniyle büyük bir psikososyal sorundur. Çocuğun cinsel istismarı ile psikiyatrik bozukluklar arasındaki ilişki bugüne kadar yapılmış birçok kesitsel ve uzunlamasına çalışmayla gösterilmiştir. Bu çalışmada, çocuk psikiyatri servisinde cinsel istismar nedeniyle yatarak tedavi görmüş olgularda, klinik iyileșme düzeyinin ölçülerek saptanması amaçlanmıştır.

Yöntem: Çalışma örneklemini, cinsel istismar nedeniyle 2005-2018 yılları arasında yataklı serviste tedavi gören 8-18 yaş arası toplam 43 çocuk ve ergen oluşturmuştur. Çalışmanın verilerini oluşturan sosyodemografik özellikler, bireysel ve ailesel risk puanlarını içeren veriler ve servise yatış ve taburculuk sırasında rutin olarak ölçülen Çocuklar için Genel Değerlendirme Ölçeği (CGAS) puanları ve Klinik Gidiş Değerlendirme Ölçeği (HoNOSCA-TR) puanları geriye dönük olarak hastane kayıtlarından elde edilmiştir.

Bulgular: Çalışmadan elde edilen sonuçlara göre serviste ortalama yatış süresi $85,74 \pm 30,54$ gün saptanmıştır. CGAS ile ölçülen genel işlevsellik düzeyi yatışa göre taburculuk sırasında anlamlı olarak artmıştır $(p<0,05)$. Ayrıca klinik iyileşme düzeyini ölçmeyi amaçlayan HoNOSCA-TR toplam ve alt ölçek puanları taburculuk sırasında yatış puanlarına göre anlamlı oranda düşmüştür $(p<0,05)$.

Sonuç: Çalışmamız, cinsel istismar nedeniyle yatarak tedavi gören çocuk ve ergenlerin, yatarak tedaviden ve günlük aktiviteler ve terapötik müdahaleler sırasında akranları ve servis ekip üyeleriyle olumlu ve onarıcı sosyal etkileşimler kurmasını sağlamayı amaçlayan bir tedavi modeli olan ortam terapisinden yararlandığını göstermiştir.

Anahtar kelimeler: Çocuğun cinsel istismarı, yataklı tedavi, ortam terapisi, iyileşme
Alındığı tarih: 31.01 .2020

Kabul tarihi: 03.02.2020 Online Yayın tarihi: 30.03 .2020

Burcu Serim Demirgoren Department of Child and Adolescent Psychiatry, Dokuz Eylul University Medical Faculty, Izmir, Turkey burcuserim@hotmail.com ORCID: 0000-0002-1659-2798

T. Guvenir 0000-0002-4933-2124

O. Simsek 0000-0003-4188-7210

B. Sen 0000-0001-5812-9876 Department of Child and Adolescent Psychiatry, Dokuz Eylul University Medical Faculty, Izmir, Turkey 


\section{INTRODUCTION}

Child sexual abuse (CSA) is a major psychosocial problem that leads to lifelong consequences and impairments that child and adolescent mental health services (CAMHS) have to tackle within a multidisciplinary approach.

Two meta-analyses of CSA including a sample size of nearly 10 million cases from a global sample provided estimated prevalence rates of $18-20 \%$ for girls and $8 \%$ for boys ${ }^{(1,2)}$.

Physical or emotional neglect/abuse, not growing up with biological parents, low parental education, and low family income are a few of several risk factors for CSA ${ }^{(3,4)}$. A longitudinal study based on both officially recorded and self-reported child abuse and neglect has shown that young motherhood, parental death, and unwanted pregnancy increase the risk for child sexual abuse ${ }^{(5,6)}$. Additionally, based on a large community sample, Walsh et al. ${ }^{(7)}$ reported an elevated risk for extra- and intra-familial sexual abuse if either one or both parents had a history of psychiatric disorders ${ }^{(6)}$.

The association between child abuse and psychiatric diagnosis as well as numerous physical and mental health problems has been identified via cross-sectional and longitudinal studies (8-13). Frequency, duration, and severity of childhood abuse increase the risk of having a primary Axis I disorder and creates a predisposition for the risk of suicide attempts among adults (13-15). Physical and sexual abuse may be independently associated with a variety of potential psychiatric outcomes among children with significant emotional and behavioral challenges ${ }^{(13,16)}$. A history of sexual abuse is associated with an increased risk of parasomnias, sexualized behavior, and being overweight or obese ${ }^{(13,17,18)}$. Additionally, sexual abuse is associated with the increased use of negative coping strategies, risk of suicide attempts and an earlier emergence of suicidality ${ }^{(13,19,20)}$.

In the literature, some studies report that as proximity levels between abusers and victims increase, psychiatric disorders occur more often (21,22). Furthermore, factors like multiple repeated attempts of sexual abuse accompanied by physical violence, abuse including penetration, and the abuser being an acquaintance, especially a family member have been found to correlate with the development of severe psychological problems in victims after the abuse ${ }^{(21,23-25)}$.

Most young people who experience sexual abuse do not require inpatient treatment but, in some cases, the severity of a patient's symptomatology and impairment in general functioning can only be contained and tackled via hospital admissions.

Many studies from various countries and cultures have indicated that child and adolescent inpatient units are effective in the treatment of individuals with various psychiatric diagnoses and conditions (26-30). In most psychiatric units, the therapeutic milieu (the physical environment and everything within it) itself is the main therapeutic approach. The Children and Young Persons Inpatient Evaluation (CHYPIE) study found that those patients who formed confiding relationships with peers in the unit tended to have better outcomes at discharge ${ }^{(31)}$. A key constituent of the therapeutic milieu for sexually abused young people whose psychic integrity and perception of fundamental trust has been severely damaged by others, especially by someone cared by the victim, is the opportunity for positive and reparative social interactions with peers and members of the therapeutic team within communal areas as well as in school, in community meetings, and during specific group activities.

This study aimed to clarify the effectiveness of inpatient treatment of CSA by investigating the improvement in children and adolescents diagnosed with CSA who have received treatment in a generic inpatient $\mathrm{CAMH}$ unit. In addition to examining the measured change in patients' general functionality and the severity of their symptoms while in the unit, we also assessed several individual and family risk factors, the length of stay in the CAMH unit, and characteristics of abuse.

\section{MATERIALS and METHODS}

\section{Design and setting}

The study is descriptive and retrospective in 
design. The study sample included all of the children and adolescents who were treated at the inpatient unit for exposure to sexual abuse between the years of 2005-2018. As a routine procedure, the clinical diagnosis of all patients treated in the unit was ascertained and refined by the consensus of the inpatient unit treatment team using clinical assessment, follow-up, and the application of relevant psychometric tests and clinical scales. We retrospectively collected data from the hospital records routinely at admission and discharge of the patients, including sociodemographic features, individual and familial risks, the Children's Global Assessment Scale (CGAS) scores, and the Turkish version of the Health of the Nation OutcomeScales-Childrenand Adolescents (HoNOSCA-TR). The differences between admission and discharge CGAS and HoNOSCA-TR scores constituted the $\triangle$ CGAS and $\triangle$ HoNOSCA-TR scores, respectively. This study was approved by the Medical Sciences Research Ethics Committee of Dokuz Eylül University with decision number 2018/05-03.

\section{Features of the inpatient unit}

The inpatient unit was founded in 2005 in Turkey with a maximum capacity of fifteen patients. The unit is a member of the Quality Network for Inpatient CAMHS (QNIC). QNIC is an initiative of the Royal College of Psychiatrists in the United Kingdom. The unit provides milieu therapy which refers to the dyadic relationship of the patient with the treatment team and with his/her peers. Young people may come for planned treatment only. The unit is staffed by a multidisciplinary team that is led by a consultant psychiatrist. There is also an on-site school that offers individual and group therapies, family therapy, and medication, as well as community meetings. The unit provides therapeutic milieu where evidencebased treatments are utilized.

\section{Measures}

The Children's Global Assessment Scale (CGAS):

The CGAS is a scale that reflects a child's or adolescent's level of functioning during a specified time period. Clinicians evaluate the child's functionality with scores ranging from 1 to $100^{(32)}$.

\section{Health of the Nation Outcome Scales - Children} and Adolescents (HONOSCA-TR):

The HONOSCA-TR is a clinical outcome measurement instrument designed to be used in child and adolescent mental health inpatient services for patients aged 3-18 years. It was developed by the University of Manchester, the Department of Health, and the Royal College of Psychiatrists. It is a routine measurement tool that evaluates behaviors, problem areas, symptoms, and the social functionality of children and adolescents with mental health problems. HONOSCA-TR is a 5-point Likert scale. The HONOSCA-TR total score is calculated as the sum of the first 13 items. A decrease in the score indicates improvement in the clinical progress during treatment ${ }^{(33)}$. The reliability study of the Turkish version was carried out in 2010 and Intraclass Correlation Coefficient was found as $0.078^{(34)}$.

\section{Individual and familial risk assessment:}

Special forms designed in accordance with QNIC norms for assessing individual and familial risks were routinely applied to all patients at admission. The individual risk assessment takes the patient's history of behaving violently, using sharp objects and/or weapons, exhibiting threatening behaviors, hurting animals, history of illegal behavior/punishment, selfharm, recent suicidal thoughts/attempts, using alcohol/substances, abuse (emotional, physical, sexual), and inappropriate sexual behavior into consideration, and notes the presence of any physical disability (26). The total individual risk score is 12 points, and higher scores indicate higher risks ${ }^{(26)}$.

Family risk assessment section includes items inquiring about insufficient supervision at home, conflicts in the family, the lack of cooperation with school, unemployment/poverty in the family, history of psychiatric disorder, self-harm/suicide in the family, lack of social support, and the presence of unemployment/poverty in the environment in which the family is living ${ }^{(26)}$. The total risk score is 8 points, and higher scores indicate higher risks ${ }^{(26)}$.

\section{Statistical analysis}

The SPSS Windows 22.0 software package was 
used to evaluate the data. In addition to the descriptive analyses, a comparison of the CGAS and HONOSCA-TR scores at admission and discharge were conducted with the Wilcoxon signed-rank test by considering the data distribution. Spearman's correlation analysis was performed to evaluate the correlation between the age, duration of hospitalization, individual and familial risks, and $\triangle C G A S$ and $\triangle$ HONOSCA-TR. In all analyses, $\mathrm{p} \leq 0.05$ was considered to be significant.

\section{RESULTS}

A total of 43 children and adolescents received inpatient treatment due to sexual abuse and were discharged with a planned process from the inpatient unit between years 2005 and 2018. Thirtry -seven ( $86 \%$ ) girls, and 6 boys (14\%) were included in the study with a mean age of $14.51 \pm 2.39$ years (minmax: 8-18 years). The duration of hospitalization was $85.74 \pm 30.54$ days (min-max: 30-184 days).

Thirty-two (74.4\%) patients had been exposed to sexual abuse including vaginal and/or anal penetration. Only $8(18.4 \%)$ patients had been abused by an unfamiliar person. Of those who were abused by a person whom he/she knows, 12 (27.9\%) of them were abused by a first-degree family member. Twenty-six (60.5\%) of the cases reported that the sexual abuse occurred more than once. Physical abuse was also accompanied in 11 (25.6\%) of those who were sexually abused. The most prevalent disorders diagnosed were mood disorders (72\%), followed by anxiety disorders (34.8\%). DSM-IV-TR axis I diagnoses of the patients are shown in Table 1.

Table 1. Diagnosis of the $\mathbf{4 3}$ patients in an inpatient unit from 2005-2018 for treatment of child sexual abuse according to DSM-IV-TR.

\begin{tabular}{lcc}
\hline & N & $\%$ \\
\hline Mood Disorders & 31 & 72.0 \\
Anxiety Disorders & 15 & 34.8 \\
Attention-Deficit/Hyperactivity Disorder & 3 & 6.9 \\
Schizophrenia and Other Psychotic Disorders & 2 & 4.6 \\
Dissociative Disorders & 1 & 2.3 \\
Trichotillomania & 1 & 2.3 \\
Eating Disorders & 1 & 2.3 \\
& & \\
\hline
\end{tabular}

The mean individual risk scores of the patients were found to be $5.74 \pm 2.52$ over 12 points, and their mean familial risk scores were calculated as $5.13 \pm 1.84$ over 8 points.

The mean CGAS score of the patients was $40.65 \pm 8.79$ at admission and $61.04 \pm 10.35$ at discharge. There was a significant increase at CGAS scores at discharge compared to admission $(p<0.001)$.

HONOSCA-TR has been used as a routine evaluation tool since 2010 in order to evaluate the level of improvement in children and adolescents treated in the inpatient unit. Since 12 patients had been admitted to the unit prior to the availability of the instrument, the scores for HONOSCA-TR could only be obtained for the remaining 31 adolescents. The mean total HONOSCA-TR scores of the patients were $27.16 \pm 8.05$ at admission and $15.80 \pm 6.79$ at discharge. The HONOSCA-TR total scores of all patients showed a significant decrease at discharge, indicating a significant level of improvement $(p<0.001)$. These data are summarized in Table 2.

Results of correlation analysis revealed that there was a significant and positive correlation between

Table 2. CGAS and HONOSCA-TR score for 43 patients at an inpatient unit for treatment of child sexual abuse at admission and discharge.

\begin{tabular}{|c|c|c|c|c|c|}
\hline & $\mathbf{N}$ & $\begin{array}{l}\text { Admission } \\
\text { Mean (SD) }\end{array}$ & $\begin{array}{l}\text { Discharge } \\
\text { Mean (SD) }\end{array}$ & $\begin{array}{c}\text { Wilcoxon } \\
\text { Z }\end{array}$ & $\mathbf{p}^{*}$ \\
\hline CGAS & 43 & $\begin{array}{l}40.65 \\
(8.79)\end{array}$ & $\begin{array}{c}61.04 \\
(10.35)\end{array}$ & -5.71 & $<0.001$ \\
\hline $\begin{array}{l}\text { HONOSCA-TR_ } \\
\text { total }\end{array}$ & 31 & $\begin{array}{l}27.16 \\
(8.05)\end{array}$ & $\begin{array}{l}15.80 \\
(6.79)\end{array}$ & -4.78 & $<0.001$ \\
\hline $\begin{array}{l}\text { HONOSCA-TR_ } \\
\text { behavioral }\end{array}$ & 31 & $\begin{array}{c}8.0 \\
(3.67)\end{array}$ & $\begin{array}{c}3.96 \\
(2.25)\end{array}$ & -4.28 & $<0.001$ \\
\hline $\begin{array}{l}\text { HONOSCA-TR_ } \\
\text { impairment }\end{array}$ & 31 & $\begin{array}{c}3.61 \\
(1.80)\end{array}$ & $\begin{array}{c}2.06 \\
(1.54)\end{array}$ & -3.78 & $<0.001$ \\
\hline $\begin{array}{l}\text { HONOSCA-TR_ } \\
\text { symptom }\end{array}$ & 31 & $\begin{array}{c}5.41 \\
(2.12)\end{array}$ & $\begin{array}{c}3.25 \\
(1.48)\end{array}$ & -3.77 & $<0.001$ \\
\hline $\begin{array}{l}\text { HONOSCA-TR_ } \\
\text { social }\end{array}$ & 31 & $\begin{array}{c}9.77 \\
(2.80)\end{array}$ & $\begin{array}{c}6.51 \\
(2.95)\end{array}$ & -4.48 & $<0.001$ \\
\hline
\end{tabular}

CGAS = Children's Global Assessment Scale; HONOSCA-TR = Health of the Nation Outcome Scales - Children and Adolescents; $S D=$ standard deviation.

* Wilcoxon signed-rank test 
Table 3. Correlation analysis of $\triangle$ CGAS and $\triangle H O N O S C A-T R$ scores in 43 patients treated for child sexual abuse at an inpatient unit.

\begin{tabular}{|c|c|c|c|c|c|c|c|c|}
\hline & \multicolumn{2}{|c|}{ Age } & \multicolumn{2}{|c|}{$\begin{array}{c}\text { Duration of } \\
\text { hospitalization }\end{array}$} & \multicolumn{2}{|c|}{$\begin{array}{l}\text { Individual } \\
\text { risk score }\end{array}$} & \multicolumn{2}{|c|}{$\begin{array}{c}\text { Familial risk } \\
\text { score }\end{array}$} \\
\hline & $\mathbf{r}$ & p & $r$ & $\mathbf{p}$ & $r$ & $\mathbf{p}$ & $r$ & $\mathbf{p}$ \\
\hline$\triangle \mathrm{CGAS}$ & \multicolumn{2}{|c|}{0.3410 .025} & \multicolumn{2}{|c|}{0.1030 .510} & \multicolumn{2}{|c|}{0.0930 .553} & -0.77 & 0.625 \\
\hline$\triangle$ HONOSCA-TR_total & \multicolumn{2}{|c|}{0.4460 .012} & \multicolumn{2}{|c|}{0.0430 .819} & \multicolumn{2}{|c|}{0.4510 .011} & -0.283 & 0.123 \\
\hline$\triangle$ HONOSCA-TR_behavioral & \multicolumn{2}{|c|}{0.2950 .107} & \multicolumn{2}{|c|}{0.1260 .499} & \multicolumn{2}{|c|}{0.5330 .002} & -0.091 & 0.625 \\
\hline$\triangle$ HONOSCA-TR_impairment & \multicolumn{2}{|c|}{0.1700 .362} & \multicolumn{2}{|c|}{0.0270 .884} & \multicolumn{2}{|c|}{0.2290 .215} & -0.345 & 0.057 \\
\hline$\triangle$ HONOSCA-TR_symptom & \multicolumn{2}{|c|}{0.2360 .201} & \multicolumn{2}{|c|}{0.1810 .331} & \multicolumn{2}{|c|}{0.2380 .197} & 0.253 & 0.169 \\
\hline$\triangle$ HONOSCA-TR_social & \multicolumn{2}{|c|}{0.2910 .112} & \multicolumn{2}{|c|}{0.0690 .712} & \multicolumn{2}{|c|}{0.1100 .555} & -0.323 & 0.076 \\
\hline
\end{tabular}

$\triangle C G A S=$ The difference between admission and discharge CGAS scores; $\triangle H O N O S C A-T R=$ The difference between admission and discharge HONOSCA-TR scores.

*Spearman correlation analysis

age difference (months) and $\triangle \mathrm{HONOSCA}$ total score $(p=0.012, r=0.446)$ and also $\triangle$ CGAS $(p=0.025$, $r=0.341)$. Another significant and positive correlation was observed between the individual risk scores and $\triangle$ HONOSCA total score $(p=0.011, r=0.451)$ and $\triangle$ HONOSCA behavioral sub-score, indicating that the inpatient treatment helped to reduce behavioral problems as well ( $p=0.002, r=0.533)$. No significant correlation was determined between the duration of hospitalization and the $\triangle$ HONOSCA or $\triangle$ CGAS scores. The results are summarized in Table 3.

\section{DISCUSSION}

Measuring the impact on young patients' mental health and identifying factors that predict a positive change in psychiatric functioning is key to supporting an inpatient approach ${ }^{(35)}$. Research amongst inpatient populations presents many challenges. The ethical and moral considerations preclude the use of a concurrent control arm as there is no equivalent alternative treatment to inpatient care ${ }^{(35)}$. Thus, determining a causal relationship between treatmentrelated variables and outcome is problematic ${ }^{(36,37)}$.

This study aimed to investigate the improvement of children and adolescents who received inpatient treatment in a generic inpatient CAMH unit for being exposed to sexual abuse. Consistent with previous research, we found that nearly $80 \%$ of the cases were abused by a person the victim knows ${ }^{(6,38)}$. Moreover, nearly $30 \%$ of the cases were abused by a first-degree family member ${ }^{(39-41)}$. Physical abuse accompanied sexual abuse in $25 \%$ of our cases, similar to the literature ${ }^{(22)}$.

Demonstrating the efficacy of inpatient treatment is particularly difficult in psychiatric inpatient units for children and adolescents due to a comparatively small number of patients, their clinical diversity, and the severity of the clinical presentation ${ }^{(42)}$. The CGAS and HONOSCA are both well-validated routine outcome measures with acceptable reliability and applicability to be used for the evaluation of the effectiveness of the inpatient psychiatric treatment of children and adolescents ${ }^{(43)}$. According to our results, general functionality measured by the CGAS significantly increased from admission to discharge following psychiatric inpatient treatment. Moreover, there were significant improvements in the total and all HONOSCA subscales such as the psychiatric symptoms, level of impairment, social and behavioral domains.

Considering the results obtained from our study, there is a significant correlation in increased functionality and improvement with age. In accordance with the literature, this finding supports the assumption that early-onset psychopathologies and abuse experienced in childhood or adolescence correlate with poor prognosis ${ }^{(26,44,45)}$.

Another finding from our study indicates that behavioral problems have also benefited from inpatient treatment. According to our results, inpatient treatment of sufficient duration applied with multidimensional perspectives, including social, educational, medical and psychological interventions, can be 
effective in the treatment of sexually abused patients. Effective treatment of sexually abused children and adolescents is critical for the successful management of their psychiatric symptoms and improvement of both their functionality and quality of life (22).

Like most of the prior studies, our study was performed using data from a single inpatient unit, so the generalization of results is limited. Despite data on CGAS and other sociodemographic and clinical data being available for all of the cases, HONOSCA-TR scores were not available for those who had been admitted to the unit prior to the completion of validity and reliability studies of the instrument. In addition, evaluation of functionality and level of improvement only by clinicians and not having a scale for evaluation by the patient and families can also be considered as another limitation.

Despite these design challenges, our study has demonstrated thaT sexually abused young people benefited from inpatient treatment, with objective evidence of outcomes of improved mental states. We strongly believe that one of the main reasons why our sexually abused young patients managed to improve in their functioning was the strength of the therapeutic milieu which facilitated positive and reparative social interactions between the patients, peers and members of the therapeutic team during daily activities as well as through therapeutic interventions. Therefore, therapeutic community structure and principles should be adopted by other agencies such as social services, care homes or foster care that provides care and support to those young people during the recovery and re-establishment in their lives.

Ethics Committee Approval: Approval was obtained from the Medical Sciences Research Ethics Committee of Dokuz Eylül University with decision number 2018/05-03 (15.02.2018).

Conflict of Interest: The Authors declare that there is no conflict of interest.

Funding: This research received no specific grant from any funding agency in the public, commercial, or not-for-profit sectors.

Informed Consent: Written informed consent was obtained.

\section{REFERENCES}

1. Pereda N, Guilera G, Forns M, Gómez-Benito J. The prevalence of child sexual abuse in community and student samples: A meta-analysis. Clin Psychol Rev. 2009;29:328-38. https://doi.org/10.1016/j.cpr.2009.02.007

2. Stoltenborgh $\mathrm{M}$, van IJzendoorn $\mathrm{MH}$, Euser EM, BakermansKranburg MJ. A global perspective on child sexual abuse: Meta-analysis of prevalence around the world. Child Maltreat. 2011;16:79-101.

https://doi.org/10.1177/1077559511403920

3. Hussey JM, Chang JJ, Kotch JB. Child maltreatment in the United states: Prevalence, risk factors, and adolescent health consequences. Pediatrics. 2006;118:933-42. https://doi.org/10.1542/peds.2005-2452

4. Laaksonen T, Sariola H, Johansson A, Jem P, Varjonen M, von der Pahlen B. Changes in the prevalence of child sexual abuse, its risk factors, and their associations as a function of age cohort in a Finnish population sample. Child Abuse Negl. 2011;35:480-90.

https://doi.org/10.1016/j.chiabu.2011.03.004

5. Brown J, Cohen P, Johnson JG, Salzinger S. A longitudinal analysis of risk factors for child maltreatment: Findings of a 17-year prospective study of officially recorded and selfreported child abuse and neglect. Child Abuse Negl. 1998;22:1065-78.

https://doi.org/10.1016/S0145-2134(98)00087-8

6. Kanamüller J, Riala K, Nivala $M$, Hakko $H$, Räsänen P. Correlates of Sexual Abuse in a Sample of Adolescent Girls Admitted to Psychiatric Inpatient Care. J Child Sex Abus. 2014;23:804-23.

https://doi.org/10.1080/10538712.2014.950401

7. Walsh C, MacMillan H, Jamieson E. The relationship between parental psychiatric disorder and child physical and sexual abuse: Findings from the Ontario Health Supplement. Child Abuse Negl. 2002;26:11-22. https://doi.org/10.1016/S0145-2134(01)00308-8

8. Cisler JM, Begle AM, Amstadter AB, Resnick HS, KmetttDanielson C, Saunders BE, et al. Exposure to interpersonal violence and risk for PTSD, depression, delinquency, and binge drinking among adolescents: Data from the NSA-R. J Trauma Stress. 2012;25:33-40. https://doi.org/10.1002/jts.21672

9. Clark DB, Bellis DE, Lynch MD, Cornelius JR, Martin CS. Physical and sexual abuse, depression and alcohol use disorders in adolescents: Onsets and outcomes. Drug Alcohol Depend. 2003;69:51-60. https://doi.org/10.1016/S0376-8716(02)00254-5

10. Clark C, Caldwell T, Power C, Stansfield SA. Does the influence of childhood adversity on psychopathology persist across the lifecourse? A 45-year prospective epidemiologic study. Ann Epidemiol. 2010;20:385-94. https://doi.org/10.1016/j.annepidem.2010.02.008

11. Fergusson DM, Horwood LJ, Lynskey MT. Childhood sexual abuse and psychiatric disorder in young adulthood: II. Psychiatric outcomes of childhood sexual abuse. J Am Acad Child Adolesc Psychiatry. 1996;35:1365-74.

https://doi.org/10.1097/00004583-199610000-00024

12. Kilpatrick DG, Ruggiero KJ, Acierno R, Saunders BE, Resnick $\mathrm{HS}$, Best CL. Violence and risk of PTSD, major depression, substance abuse/dependence, and comorbidity: Results from the National Survey of Adolescents. J Consult Clin Psychol. 2003;71:692-700. 
https://doi.org/10.1037/0022-006X.71.4.692

13. Keeshin BR, Strawn JR, Luebbec AM, Saldaña SN, Wehry AM, DelBello MP et al. Hospitalized youth and child abuse: A systematic examination of psychiatric morbidity and clinical severity. Child Abuse Negl. 2014;38:76-83. https://doi.org/10.1016/j.chiabu.2013.08.013

14. Pérez-Fuentes G, Olfson M, Villegas L, Morcillo C, Wang S, Blanco C. Prevalence and correlates of child sexual abuse: $A$ national study. Compr Psychiatry. 2013;54:16-27. https://doi.org/10.1016/j.comppsych.2012.05.010

15. Sugaya L, Hasin DS, Olfson M, Lin KH, Balnco C. Child physical abuse and adult mental health: A national study. J Trauma Stress. 2012;25:384-92. https://doi.org/10.1002/jts.21719

16. Garland AF, Landsverk JL, Hough RL. Type of maltreatment as a predictor of mental health service use for children in foster care. Child Abuse Negl. 1996;20:675-88. https://doi.org/10.1016/0145-2134(96)00056-7

17. Keeshin BR, Luebbe AM, Strawn JR, Saldaña SN, Wehry AM, DelBello MP. Sexual abuse is associated with obesity in psychiatrically-hospitalized children and adolescents. J Pediatr. 2013;163:154-9. https://doi.org/10.1016/j.jpeds.2012.12.091

18. Sadeh A, Hayden RM, McGuire JP, Sachs H, Civita R. Somatic, cognitive and emotional characteristics of abused children in a psychiatric hospital. Child Psychiatry Hum Dev. 1994;24:191200.

https://doi.org/10.1007/BF02353196

19. Brent DA, Greenhill LL, Compton S, Emslie G, Wells K, Walkup JT et al. The Treatment of Adolescent Suicide Attempters study (TASA): Predictors of suicidal events in an open treatment trial. J Am Acad Child Adolesc Psychiatry. 2009;48:98796.

https://doi.org/10.1097/CHI.0b013e3181b5dbe4

20. Cohen Y, Spirito A, Sterling C, Donaldson D, Plummer B, Avilia $R$ et al. Physical and sexual abuse and their relation to psychiatric disorder and suicidal behavior among adolescents who are psychiatrically hospitalized. J Child Psychol Psychiatry. 1996;37:989-93. https://doi.org/10.1111/j.1469-7610.1996.tb01495.x

21. Fergusson DM, Boden JM, Horwood LJ. Exposure to childhood sexual and physical abuse and adjustment in early adulthood. Child Abuse Negl. 2008;32:607-19.

https://doi.org/10.1016/j.chiabu.2006.12.018

22. Kmett JA, Eack SM. Characteristics of sexual abuse among individuals with serious mental illnesses. J Interpers Violence. 2018;33:2725-44. https://doi.org/10.1177/0886260516628811

23. Green JG, McLaughlin KA, Berglund PA, Gruber MJ, Sampson NA, Zaslavsky AM et al. Childhood adversities and adult psychiatric disorders in the National Comorbidity Survey Replication (NCSR)I: Associations with first onset of DSM-IV disorders. Arch Gen Psychiatry. 2010;67:113-23. https://doi.org/10.1001/archgenpsychiatry.2009.186

24. Kendler KS, Bulik CM, Silberg J, Hettema JM, Myers J, Prescott CA. Childhood sexual abuse and adult psychiatric and substance use disorders in women: An epidemiological and cotwin control analysis. Arch Gen Psychiatry. 2000;57:953-9. https://doi.org/10.1001/archpsyc.57.10.953

25. Widom CS, DuMont K, Czaja SJ. A prospective investigation of major depressive disorder and comorbidity in abused and neglected children grown up. Arch Gen Psychiatry. 2007;64:49-56. https://doi.org/10.1001/archpsyc.64.1.49

26. Demirgoren BS, Ozbek A, Gencer O. Factors affecting improvement of children and adolescents who were treated in the child and adolescent psychiatry inpatient unit. J Int Med Res. 2017;45:1318-23. https://doi.org/10.1177/0300060517713833

27. Güvenir T, Varol Taş F, Özbek A. Child and adolescent mental health inpatient services in Turkey:Is there a need and are they effective? Noro Psikiyatr Ars. 2009;46:143-8.

28. Jaffa T, Stott C. Do patients on adolescent units recover? A study of outcome and acceptability of treatment. Eur Child Adolesc Psychiatry. 1999;8:292-300. https://doi.org/10.1007/s007870050104

29. O'Herlihy A, Worrall A, Lelliott P, Jaffa T, Banerjee S. Distribution and characteristics of the patient in child and adolescent mental health services in England. Br J Psychiatry. 2003;183:547-51. https://doi.org/10.1192/02-620

30. Özbaran B, Köse S, Yılmaz E, Aydın AN, Aydın C. Evaluation of the contribution of inpatient services and experiences on improvement in child and adolescent psychiatry practice. Anadolu Psikiyatri Derg. 2016;17:120-6. https://doi.org/10.5455/apd.184670

31. Green J, Jacobs B, Beecham J, Dunn G, Kroll L, Tobias C et al. Inpatient treatment in child and adolescent psychiatry- $a$ prospective study of health gain and costs. J Child Psychol Psychiatry. 2007;48:1259-67. https://doi.org/10.1111/j.1469-7610.2007.01802.x

32. Shaffer D, Gould MS, Brasic J, Ambrosinin P, Fisher P, Bird H et al. A childrens global assessment scale (CGAS). Arch Gen Psychiatry. 1983;40:1228-31. https://doi.org/10.1001/archpsyc.1983.01790100074010

33. Gowers SG, Harrington RC, Whitton A, Beevor P, Lelliott JK, Wing RJ. Health of the Nation Outcome Scales for Children and Adolescents (HoNOSCA). Glossary for HoNOSCA score sheet. Br J Psychiatry. 1999;174:428-31. https://doi.org/10.1192/bjp.174.5.428

34. İşcanlı L, Güvenir T, Taş FV. Validity and Reliability of the Turkish Version of Health of the Nation Outcome Scales for Children and Adolescents (HoNOSCA). $20^{\text {th }}$ National Congress on Child and Adolescent Psychiatry Suppl. 2010:131.

35. Kennedy J, Hembry P, Green D, Skuse D, Lewis S. Predictors of change in global psychiatric functioning at an inpatient adolescent psychiatric unit: A decade of experience. Clin Child Psychol Psychiatry. 2020. https://doi.org/10.1177/1359104519898215

36. Blanz B, Schmidt M. Practitioner Review: Preconditions and outcome of inpatient treatment in child and adolescent psychiatry. J Child Psychol Psychiatry. 2000;41:703-12. https://doi.org/10.1111/1469-7610.00658

37. Green J, Kroll L, Imrie D, Frances FM, Begum K, Anson R. Health gain and outcome predictors during inpatient and related day treatment in child and adolescent psychiatry. J Am Acad Child Adolesc Psychiatry. 2001;40:325-32. https://doi.org/10.1097/00004583-200103000-00012

38. Valle R, Bernabé-Ortiz A, Gálvez-Buccollini JA, Gutiérrez C, Martin SS. Intrafamilial and extrafamilial sexual assault and its association with alcohol consumption. Rev Saude Publica. 2018;52:1-10. https://doi.org/10.11606/S1518-8787.2018052000539

39. Bernet W. Practice parameters for the forensic evaluation of children and adolescents who may have been physically or sexually abused. J Am Acad Child Adolesc Psychiatry. 1997;36:37-56. 
https://doi.org/10.1097/00004583-199710001-00004

40. Fischer DG, McDonald WL. Characteristics of intrafamilial and extrafamilial child sexual abuse. Child Abuse Negl. 1998;22:915-29.

https://doi.org/10.1016/S0145-2134(98)00063-5

41. Jain AM. Emergency department evaluation of child abuse. Emerg Med Clin North Am. 1999;17:575-93.

https://doi.org/10.1016/S0733-8627(05)70083-3

42. Garralda M, Rose G, Dawson R. Measuring outcomes in a child psychiatry inpatient unit. J Child Serv. 2008;3:6-16. https://doi.org/10.1108/17466660200800015

43. Ford T, Tingay $K$, Wolpert $M$; the CORC Steering Group. CORC's survey of routine outcome monitoring and national
CAMHS dataset developments: A response to Johnston and Gower. Child and Adolescent Mental Health. 2006;11:50-2. https://doi.org/10.1111/j.1475-3588.2005.00390.x

44. Egger HL, Angold A. Common emotional and behavioral disorders in preschool children: presentation, nosology and epidemiology. J Child Psychol Psychiatry. 2006;47:313-37. https://doi.org/10.1111/j.1469-7610.2006.01618.x

45. Setoya Y, Saito K, Kasahara M, Watanabe K, Kodaira M, Usami M. Evaluating outcomes of the child and adolescent psychiatric unit: A prospective study. Int J Ment Health Syst. 2011;5:1-8.

https://doi.org/10.1186/1752-4458-5-7 